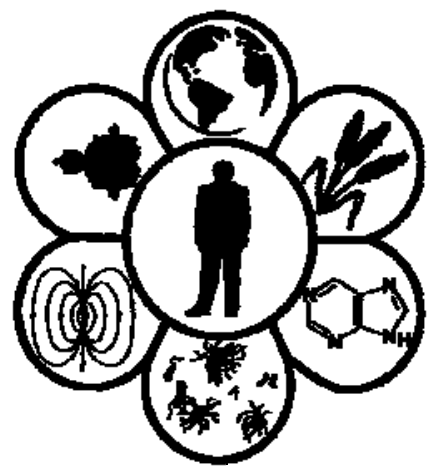

Вісник Дніпропетровського університету. Біологія, медицина Vìsnik Dnìpropetrovs'kogo unìversitetu. Seriâ Bìologiâ, medicina Visnyk of Dnipropetrovsk University. Biology, medicine

Vìsn. Dnìpropetr. Unìv. Ser. Bìol. Med. 2014. 5(1), 66-70. doi: $10.15421 / 021414$

ISSN 2310-4155 print ISSN 2312-7295 online www.medicine.dp.ua

УДК 577.156:612.015

\title{
Вплив гіпертиреозу на процеси навчання та стан гліальних проміжних філаментів головного мозку щурів
}

\author{
С.В. Кириченко, В.С. Недзвецький
}

\author{
Дніпропетровський національний університет імені Олеся Гончара, Дніпропетровськ, Україна
}

\begin{abstract}
Досліджено вплив гіпертиреозу на показники окисного стресу, стан гліальних проміжних філаментів і пам'ять. У мозку щурів iз гіпертиреозом визначено достовірне зростання вмісту продуктів перекисного окиснення ліпідів і погіршення процесу запам’ятовування. Час збереження пам'яті у тесті умовного рефлексу пасивного уникнення був відмінним у групі щурів, які отримували тироксин, порівняно з контролем. Зниження періоду очікування у тесті умовного рефлексу пасивного уникнення становило $67 \%(P<0,01)$ порівняно 3 контролем. Такі значні відмінності вказують на погіршення процесу навчання та запам'ятовування у групі щурів із гіпертиреозом. Зміни поліпептидного складу виявлені в гіпокампі та корі великих півкуль. У гіпокампі щурів із гіпертиреозом відмічається збільшення інтенсивності поліпептидних зон як розчинної, так і філаментної форм гліального фібрилярного кислого білка. Дослідження показників кореляції виявило високий ступінь кореляції між умістом ГФКБ і рівнем продуктів перекисного окиснення. Ці дані вказують на важливу роль окисного стресу в індукції астрогліальної реактивної відповіді за умов гіпертиреозу. Отримані результати вказують на можливість реконструкції цитоскелета гліальних клітин під впливом тироїдних гормонів.
\end{abstract}

Ключові слова: гіпертиреоз; окисний стрес; гліальні проміжні філаменти

\section{Hyperthyreosis effects on the learning and glial intermediate filaments of rat brain}

\author{
S.V. Kyrychenko, V.S. Nedzvetsky \\ Oles Honchar Dnipropetrovsk National University, Dnipropetrovsk, Ukraine
}

The influence of hyperthyreosis on oxidative stress, state of glial intermediate filaments and memotry was investigated. Significant increasing of lipid peroxidation products into both hippocampus and cortex and change for the worse of memory was observed. Analysis of the behavioral reactions of rats in the test of passive avoidance conditioned reflex showed that the acquisition of skills of all groups of animals did not differ by time waiting period (latent period). Time saving memory test conditioned reflex of passive avoidance was excellent in the group of rats treated with thyroxine compared with controls. The change of polypeptide GFAP was observed in hippocampus and cortex. Both soluble and filamentous forms of GFAP increased in hippocampus of rat with hyperthyreosis. In filament fractions, increase in the intensity of $49 \mathrm{kDa}$ polypeptide band was found. In the same fraction of insoluble cytoskeleton proteins degraded HFKB polypeptides with molecular weight in the region of 46-41 kDa appeared. Marked increase of degraded polypeptides was found in the soluble fraction of the brain stem. The intensity of the intact polypeptide ( $49 \mathrm{kDa})$, as well as in the filament fraction, significantly increased. It is possible that increasing concentrations of soluble subunits glial filaments may be due to dissociation of own filaments during the reorganization of cytoskeleton structures. Given the results of Western blotting for filament fraction, increased content of soluble intact $49 \mathrm{kDa}$ polypeptide is primarily the result of increased expression of HFKB and only partly due to redistribution of existing filament structures. Calculation and analysis of indicators showed high correlation between the increase in content and peroxidation products of HFKB. These results indicate the important role of oxidative stress in the induction of astroglial reactive response under conditions of hyperthyroidism. This data shows the possibility of the glial cell cytoskeleton reconstruction under effect of thyroid hormones.

Keywords: hyperthyreosis; oxidative stress; glial intermediate filaments

Дніпропетровський національний університет імені Олеся Гончара, пр. Гагаріна, 72, Дніпропетровськ, 49010, Україна. Oles Honchar Dnipropetrovsk National University, Gagarin Ave., 72, Dnipropetrovsk, 49010, Ukraine.

Tel.: +38-095-338-61-79.E-mail: svetavk@ukr.net,nedzvetskyvictor@ukr.net 


\section{Вступ}

Гормони щитовидної залози - важливі посередники молекулярних, клітинних і фізіологічних процесів, які регулюють розвиток мозку ссавців, диференціацію клітин, їх міграцію на ранніх стадіях онтогенезу, експресію деяких генів, чутливих до впливу як дефіциту гормонів щитовидної залози, так і їх надлишку. Фізіологічна роль гормонів щитовидної залози полягає в координації процесів розвитку мозку за допомогою впливу на експресію окремих генів i швидкість диференціації клітин. Існують експериментальні докази можливої участі тироїдних гормонів i їх рецепторів у диференціації нейронів і гліальних клітин, а також у контрольованій загибелі клітин (Bernal and Nunez, 1995). Вплив гормона щитовидної залози на нейрональну диференціацію може реалізовуватися за допомогою регуляції експресії деяких генів. Останніми роками відносно велику кількість тироїдзалежних генів ідентифіковано в мозку ссавців (Motomura and Brent, 1998). Концентрація тиреотропного гормона в крові не корелює 3 варіабельністю ознак, що спостерігаються у пацієнтів із тиреотоксикозами.

Широко досліджені ефекти гіпофункції щитовидної залози на процеси розвитку клітин ЦНС. У той же час залишаються нез'ясованими питання впливу надмірних концетрацій тироїдних гормонів (ТГ) на функції нейронів і гліальних клітин. Не розкриті також причини розвитку пізнавального дефіциту у випадку порушень балансу нейрогормонів.

Незважаючи на те, що тироїдні гормони та їх вплив добре досліджені, вивчено лише обмежену кількість маркерів, які безпосередньо відображають дію гормона. У ролі маркерів, що адекватно відповідають на зміни концентрації ТГ, розглядаються цитоскелетні білки. $С$ дані про те, що ТГ регулює експресію тубуліну (Nunez et al., 1992), модулює експресію важкого ланцюга міозину у разі денервації скелетних м'язів ТГ, впливає на процес полімеризації F-актину і таким чином контролює організацію відповідних цитоскелетних структур (Haddad et al., 2007).

Білки проміжних філаментів розглядаються як надійні гістоспецифічні маркери. У нервовій тканині проміжні філаменти представлені триплетом білків нейрофіламентів і гліальним фібрилярним кислим білком (ГФКБ). Існують дані про зміну структури проміжних філаментів і фізико-хімічних властивостей цитоскелетних білків за патологій різної етіології та дії ушкоджувальних факторів (Farvell et al., 1995). Велике значення має вивчення та використання проміжних філаментів як маркерів розвитку патологічних станів нервової системи. Дослідження молекулярних маркерів, характерних для тиреотоксикозів, має особливе значення у зв'язку з постійно зростаючим забрудненням навколишнього середовища, що викликє надмірну продукцію тиреотропних гормонів. Є дані про те, що синтез ТГ істотно підвищений у дітей, опромінених під час вагітності матері внаслідок Чорнобильської катастрофи, а також у дітей, які проживають у районах спільного впливу солей важких металів і малих доз радіації (Baydas et al., 2007).

Мета статті - оцінити показники окисного стресу, вміст i поліпептидний склад білка гліальних проміжних філаментів ГФКБ у різних відділах головного мозку та поведінкові реакції щурів за умов експериментального гіпертиреозу.

\section{Матеріал і методи досліджень}

Щури лінії Вістар (масою 200-230 г) протягом 14 діб отримували перорально тироксин. Динаміка отримання тироксину: початкова доза (10 мкг/добу) нарощувалася по 10 мкг/добу протягом 14 діб. До експерименту брали тварин 3 концентрацією тироксину у сироватці крові не менше 17 нг/мл. Здатність до запам'ятовування оцінювали у тесті «умовної реакції пасивного уникнення» (УРПУ). Викликані тиреотоксикозом зміни білка гліальних проміжних філаментів оцінювали по досягненні дози 140 мкг за 24 години. Після декапітації вилучали головний мозок, охолоджували та розділяли на відділи. 0,2 г тканини (головний мозок загалом, кора великих півкуль, мозочок, середній мозок) гомогенізували в 4,0 мл 0,025 М трис-буфері ( $p H 8,0)$, що містив 2 мМ ЭДТА, 1 мМ 2-меркаптоетанол, 0,1 мМ фенілметилсульфонілфторид і соєвий інгибітор трипсину (10 мкг/мл). Гомогенат центрифугували при $30000 \mathrm{~g}$ протягом 60 хв. Супернатант $\left(\mathrm{S}_{1}\right)$ містив розчинні білки. Осадок ресуспендували в 0,5 мл тієї ж буферної системи, яка додатково містила $4 \mathrm{M}$ сечовину. Супернатант, який отримували після другого центрифугування $\left(\mathrm{S}_{2}\right)$, містив нерозчинні білки проміжних філаментів. Вміст загального білка в екстрактах визначали методом Лоурі в модифікації Міллера (Miller, 1959). Визначення поліпептидного складу гліальних філаментів проводили за допомогою імуноблотингу 3 використанням поліклональної моноспецифічної антисироватки у розведенні 1:1500, як описано раніше. Кількісний аналіз ГФКБ проводили за допомогою комп'ютерної обробки сканованих результатів імуноблотингу (LabWork 4.0). Рівень перекисного окислення ліпідів вимірювали 3 використанням тестнабору LPO-586 (Oxis Int. Inc., USA).

Обробку одержаних даних проводили методами математичної статистики для малих вибірок. Відносний вміст ГФКБ виражали у вигляді середньої величини \pm стандартна похибка, достовірну різницю між групами оцінювали із застосуванням $t$-критерію Стьюдента $(P<0,05)$ після перевірки гіпотез про нормальність розподілу та різницю між генеральними дисперсіями.

\section{Результати та їх обговорення}

Однією 3 важливих причин функціональних ускладнень у клітинах нервової тканини вважається розвиток окисного стресу (Hattori and Oikawa, 2007). Із метою контролю змін показників окисно-відновного балансу в гіпокампі, корі великих півкуль і 
стовбурі мозку визначали рівень ТБК-реактивних продуктів (малоновий діальдегід + 4-гідроксиалкенів, ДК). Результати визначення кінцевих продуктів перекисного окиснення ліпідів у гомогенатах головного мозку експериментальних і контрольних щурів наведено на рисунку 1. В усіх досліджених відділах мозку тварин експериментальної групи рівень малонового діальдегіду + 4-гідроксиалкенів був достовірно підвищений відносно контрольної групи.

У дослідженій експериментальній моделі гіпертиреоз викликав достовірне підвищення вмісту ТБК-реактивних продуктів у гіпокампі на 68\%, стовбурі мозку - на 49\%, корі великих півкуль - на $57 \%$ порівняно 3 контролем (див. рис. 1). Таким чином, отримані результати свідчать про розвиток стійкого окисного стресу у нервовій тканині щурів за умов порушення балансу ТГ.

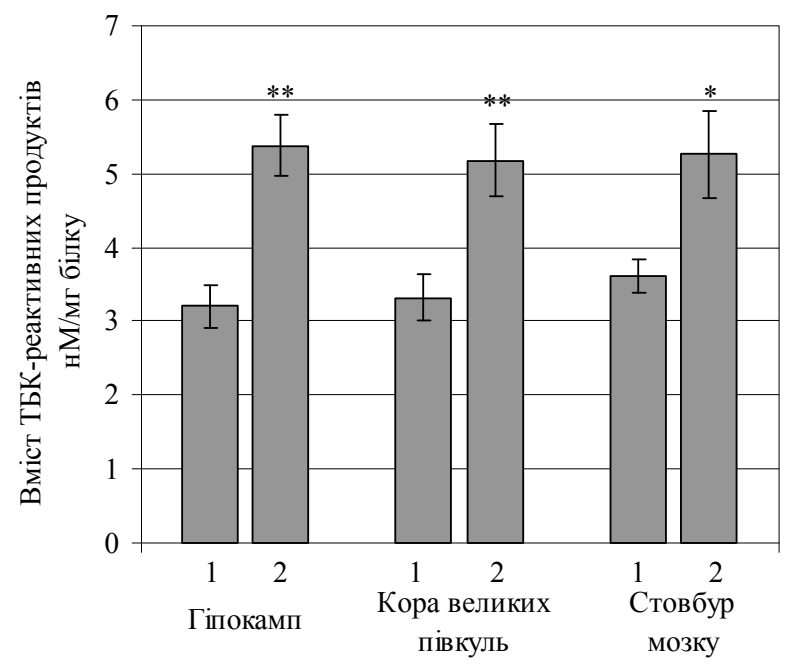

Рис. 1. Вміст ТБК-реактивних продуктів перекисного окиснення ліпідів у мозку щурів:

1 - контрольна группа, 2 - група щурів

із гіпертиреозом; * $-P<0,05, * *-P<0,01$ відносно контрольної групи

Існує обмежена кількість комплексних даних про нейротоксичні ефекти гіпертиреозу на розвиток окисного стресу, структурні нервовоспецифічні білки та поведінку, пам'ять. Різні за природою ушкоджувальні фактори та метаболічні розлади індукують генерацію реактивних сполук кисню у нервовій тканині та розвиток інсульту (Nedzvetskii et al., 2006) можуть впливати на експресію та рециклінг цитоскелетних і мембранних білків (Baydas et al., 2004), щільність синаптичних контактів (Venero et al., 2006) і таким чином порушувати процеси навчання та пам'яті.

Аналіз поведінкових реакцій щурів у тесті умовного рефлексу пасивного уникання показав, що до набуття навичок усі групи тварин не відрізнялися за часом періоду очікування (латентного періоду). Час збереження пам'яті у тесті умовного рефлексу пасивного уникнення був відмінним у групі щурів, які отримували тироксин порівняно $з$ контролем. Зниження періоду очікування у тесті умовного рефлексу пасивного уникнення становило $67 \%(P<0,01)$ порівняно 3 контролем. Такі значні відмінності вказують на погіршення процесу навчання та запам'ятовування у групі щурів із гіпертиреозом.

Із метою дослідження впливу гіпертиреозу на стан астроглії та іiі реактивність у гіпокампі, корі великих півкуль і стовбурі мозку визначали вміст і склад поліпетидних фрагментів ГФКБ. Достовірні відмінності вмісту астроцитарного цитоскелетного маркера ГФКБ визначені у фракціях розчинних і філаментних білків із мозку щурів експериментальної групи. Найсуттєвіше підвищення вмісту ГФКБ філаментної фракції виявлене в корі великих півкуль і гіпокампі щурів, які отримували тироксин (рис. 2). У гіпокампі тварин цієї групи виявлене збільшення вмісту ГФКБ у 1,74 раза $(P<0,01)$, корі великих півкуль - у $1,63(P<$ $0,01)$, стовбурі мозку - у $1,45(P<0,05)$ порівняно 3 контрольною групою.

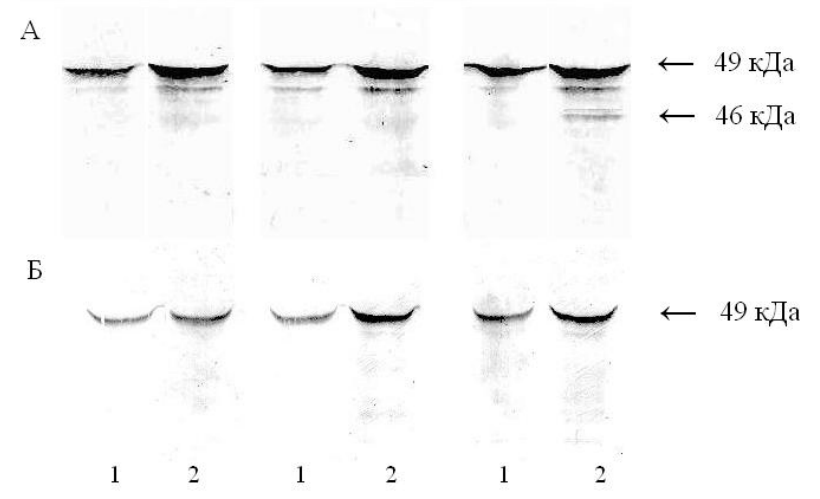

Рис. 2. Результати імуноблотингу філаментних і розчинних фракцій білків проміжних філаментів: $A$ - філаментна фракція, $E$ - розчинна фракція; 1 - контрольна група, 2 - група щурів із гіпертиреозом

Створений експериментально стан гіпертиреозу відбивається також на стані гліальних проміжних філаментів. Зміни поліпептидного складу ГФКБ виявлені в усіх відділах мозку, що були досліджені. Результати імуноблотингу філаментних і розчинних фракцій білків проміжних філаментів наведено на рисунку 2. У філаментних фракціях усіх досліджених відділів виявлено збільшення інтенсивності поліпептидної зони 49 кДа. У цій же фракції нерозчинних цитоскелетних білків з'являються деградовані поліпептиди ГФКБ $3 \mathrm{Mr}$ в області 41-46 кДа. У розчинній фракції стовбура мозку не виявлено помітного збільшення деградованих поліпептидів. Інтенсивність інтактного поліпептиду 49 кДа, так само як і у філаментній фракції, істотно зростає. Не виключено, що підвищення вмісту розчинних субодиниць гліальних філаментів може відбуватися внаслідок дисоціації власне філамента під час реорганізації цитоскелетних структур. Враховуючи результати імуноблотингу філаментної фракції, збільшення вмісту розчинного інтактного поліпептиду 49 кДа, найвірогідніше, є результатом підвищеної експресії ГФКБ.

У сечовинній (філаментній) фракції представлені в основному субодиниці ГФКБ, що безпосередньо складають філамент. Таким чином, значне збільшення інтенсивності поліпептидної зони 49 кДа у 
філаментній фракції свідчить на користь того, що підвищення концентрації ТГ може бути причиною активції фібрилогенезу у гліальних клітинах і розвитку астрогліозу.

Розрахунок і аналіз показників кореляції виявив високий ступінь кореляції між умістом ГФКБ і рівнем продуктів перекисного окиснення: у гіпокампі $-0,74 \pm$ $0,084(P<0,01)$, у корі великих півкуль $-0,71 \pm 0,093$ $(P<0,01)$, у стовбурі мозку $-0,62 \pm 0,096(P<0,05)$. Ці дані вказують на важливу роль окисного стресу в індукції астрогліальної реактивної відповіді за умов гіпертиреозу. Ефекти ТГ на астрогліальні клітини реалізуються через реорганізацію їх цитоскелета, яка контролюється ступенем фосфорилювання ГФКБ (Zamoner et al., 2007).

Роль ТГ у дозріванні астроцитів залишається не зовсім зрозумілою. Вплив ТГ на процеси дозрівання мозку реалізується також через їх взаємодію з ядерними рецепторами та регуляцію генної експресії. Зниження концентраціїі ТГ частково блокує диференціацію астроцитів. За останні 10 років зроблено значний прогрес у розкритті механізму перетворення $\mathrm{T}_{3}$ сигналу у клітинну відповідь. Ядерні рецептори ТГ функціонують по типу апорецепторів. Тобто вони мають активність за відсутності гормона, а стимуляція $\mathrm{T}_{3}$ діє як репресор транскрипції окремих генів (Bernal, 2005, 2007). Всі ізоформи трийодтиронінового рецептора експресуються в мозку. Просторова та тимчасова експресія цих рецепторів може бути основою створення у ході розвитку унікальних нейрональних ансамблів. Один із шляхів впливу на нейрональну диференціацію може реалізовуватися внаслідок дії ТГ на виробництво нейротропів та їх рецепторів (Bernal and Nunez, 1995).

Клітинні рецептори ТГ залучаються до процесів міграції клітин, синаптогенезу як у ході розвитку нервової системи, так і в дорослому мозку. Експресія мутантних рецепторів ТГ у дорослих мишей індукує стійкі поведінкові зміни, синдром тривожності та морфологічні зміни у гіпокампі (Bernal, 2007). Це вказує на важливу регуляторну роль балансу ТГ протягом усього життя.

С дані про вплив ТГ на стан окремих компонентів цитоскелета: мікрофіламентів, мікротрубочок i проміжних філаментів. В агрегованих культурах клітин ТГ стимулює експресію білків нейрофіламентів, а також появу обмежувальних гліальних клітин із надмірно розвиненими волокнами (Trentin et al., 2003). Адгезія астроцитів порушується за відсутності ТГ, що відбивається на нейрон-гліальних контактах. Таким чином, астроцитзалежне регулювання адгезивних взаємодій забезпечує механізм, за допомогою якого ТГ може впливати на міграцію нервових клітин і формування нейрональних зв'язків. Гіпертиреоз викликає багатофакторіальні метаболічні порушення, які можуть спричинювати нейротрофічні, нейромодуляторні та функціональні розлади. Надмірна концентрація ТГ викликає стійкі метаболічні порушення у нервових клітинах. Тривалий метаболічний розлад у клітинах ЦНС може відбиватись на функціях вищої нервової діяльності, зокрема, як дефіцит пізнавальної активності.
Результати тесту умовного рефлексу пасивного уникання свідчать про можливий зв'язок між розвитком окисного стресу, надмірним i тривалим астрогліозом і пізнавальним дефіцитом у групі щурів iз гіпертиреозом. Існують експериментальні докази того, що у щурів із гіпотиреозом мозок тривалий час залишається незрілим. Автори передбачають, що ТГ забезпечує синхронізацію зростання аксонів i дендритів (Nunez et al., 1992). Швидкість формування мікротрубочок збільшується 3 віком, причому це збільшення уповільнюється в умовах гіпотиреозу та відновлюється ТГ. Експресія принаймні п'яти білків, які регулюють стан тубулінових філаментів, перебуває під тироїдним контролем (Nunez, 1985). Зміна складу таких білків контролює кількість і довжину мікротубочок під час формування нейритів у процесі диференціації. Можливо, ТГ є одним із чинників, який визначає послідовність експресії генів, що регулюють процеси диференціації.

Показано, що в неокортексі та мозочку після стимуляцйї $\mathrm{T}_{3}$ активується транскрипційна регуляція та експресія не всіх, а у першу чергу нервовоспецифічних білків (Andres-Barquin et al., 1994). Диференціальна регуляція експресії у клітинах нервової системи сприяє встановленню стаціонарного стану, спрямованій та регульованій адаптації клітин у відповідь на зовнішні сигнали та опосередкованій гормональною регуляцією. Механізм гормональної регуляції ТГ може бути одним із факторів мікрооточення нервових клітин, модулюючи їх специфічну відповідь на дію стимулів різної природи. Несприятливі фактори різної природи можуть впливати на метаболізм ТГ. Порушення гормонального балансу індукує метаболічні порушення, які відбиваються як на функціонуванні окремих нервових клітин, так і на ЦНС у цілому.

Передбачають, що в онтогенезі мозку існує лише короткий період, протягом якого нервові клітини чутливі до дії ТГ. Незважаючи на це, існують дані про вплив гіпертиреозу на сформовану нервову систему. У ліквідаторів наслідків аварії на ЧАЕС із патологією щитовидної залози захворюваність хворобами нервової системи та органів чуття підвищена в 7,7 раза (Eng et al., 2000). Трийодтиронін має множинні ефекти на нервові клітки. $С$ дані про те, що ТГ активує транспорт глюкози та метаболічну активність астроцитів. Інтенсифікація фібрилогенезу у гліальних клітинах може бути пов'язана з цим ефектом ТГ.

Раніше було показано, що проміжні філаменти схильні до протеолізу $\mathrm{Ca}^{2+}$-залежними протеїназами калпаїнами (Eng et al., 2000). В експериментах на тваринах виявлено, що в умовах гіпертиреозу порушується гомеостаз $\mathrm{Ca}^{2+}$. Це дозволяє передбачити, що ТГ може також впливати на стан проміжних філаментів за допомогою модулювання активності $\mathrm{Ca}^{2+}$-залежних протеїназ. Цитоскелет еукаріотичних клітин розглядають на сьогодні не тільки як структурний інтегратор, а і як активний модулятор цілої низки клітинних процесів i функцій. Можливо, гліальні проміжні філаменти залучаються до процесів, що викликаються дією ТГ. 
Отримані результати вказують на щільний зв'язок між розвитком окисного стресу в нервовій тканині, реактивацією астроцитів та пізнавальним дефіцитом у щурів за умов гіпертиреозу. Виявлені зміни поліпептидного складу проміжних філаментів глії свідчать про певну пластичність астроцитарного цитоскелета в умовах тиреотоксикозу. Ідентифікація мережі генів, експресія яких чутлива до регуляції гормоном щитовидної залози у період розвитку мозку та у зрілій нервовій системі, з'ясування механізмів регуляції та фізіологічної ролі продуктів цих генів залишаються головною метою майбутніх досліджень.

\section{Висновки}

В умовах експериментального гіпертиреозу відбуається суттєве підвищення вмісту ТБКреактивних продуктів у відділах мозку щурів (гіпокампі - на 68\%, стовбурі - 49\%, корі великих півкуль - на 57\% порівняно з контрольною групою). Визначено збільшення вмісту астроцитарного цитоскелетного маркера ГФКБ та поліпептидного складу мозку щурів експериментальної групи, які корелюють 3 умістом ТБК-реактивних продуктів.

\section{Бібліографічні посилання}

Andres-Barquin, P.J., Fages, C., Le Prince, G., Rolland, B., Tardy, M., 1994. Thyroid hormones influence the astroglial plasticity: Changes in the expression of glial fibrillary acidic protein (GFAP) and of its encoding message. Neurochem. Res. 19(1), 65-69.

Baydas, G., Koz, S.T., Tuzcu, M., Etem, E., Nedzvetsky, V.S., 2007. Melatonin inhibits oxidative stress and apoptosis in fetal brains of hyperhomocysteinemic rat dams. J. Pineal. Res. 43(3), 225-231.

Baydas, G., Donder, E., Kiliboz, M., Sonkaya, E., Tuzcu, M., Yasar, A., Nedzvetskii, V.S., 2004. Neuroprotection by $\alpha$-lipoic acid in streptozotocin-induced diabetes. Biochem. (Mosc.) 69(9), 1233-1238.

Bernal, J., 2005. Thyroid hormones and brain development. Vitam. Horm. 71, 95-122.
Bernal, J., 2007. Thyroid hormone receptors in brain development and function. Nat. Clin. Pract. Endocrinol. Metab. 3(3), 249-259.

Bernal, J., Nunez, J., 1995. Thyroid hormones and brain development. Europ. J. Endocrinol. 133(4), 390-398.

Eng, L.F., Ghirnikar, R.S., Lee, Y.L., 2000. Glial fibrillary acidic protein: GFAP-thirty-one years (1969-2000). Neurochem. Res. 25(9), 1439-1451.

Farvell, K., Tranter, C., Leonard, J.L., 1995. Thyroxinedependent regulation of integrin-laminin interaction in astrocytes. Endocrinology 136(9), 3909-3915.

Haddad, F., Arnold, K., Zeng, M., Boldwin, K., 1997. Interaction of thyroid state and denervation on skeletal myosin heavy chain expression. Muscle Nerve 20(12), 1487-1496.

Hattori, F., Oikawa, S., 2007. Peroxiredoxins in the central nervous system. Subcell. Biochem. 44, 357-374.

Miller, G.L., 1959. Protein determination for large numbers of samples. Anal. Chem. 31(5), 964-966.

Motomura, K., Brent, G.A., 1998. Thyreotoxicosis. Endocrinol. Metab. Clin. North Am. 27(1), 1-23.

Nedzvetskii, V.S., Tuzcu, M., Yasar, A., Tikhomirov, A.A., Baydas, G., 2006. Effects of vitamin E against aluminum neurotoxisity in rats. Biochem. (Mosc.) 71(3), 239-244.

Nunez, J., 1985. Microtubules and brain development: The effects of thyroid hormones. Neurochem. Int. 7(6), 959-968.

Nunez, J., Couchie, D., Aniello, F., Bridoux, A.M., 1992. Thyroid hormone effects on neuronal differentiation during brain development. Acta Med. Austriaca. 19(1), 36-39.

Trentin, A.G., De Aguiar, C.B., Garcez, R.C., Alvarez-Silva, M., 2003. Thyroid hormone modulates the extracellular matrix organization and expression in cerebellar astrocyte: Effects on astrocyte adhesion. Glia 42(4), 359-369.

Venero, C., Herrero, A.I., Touyarot, K., Cambon, K., LopezFernandez, M.A., Berezin, V., Bock, E., Sandi, C., 2006. Hippocampal up-regulation of NCAM expression and polysialylation plays a key role on spatial memory. Eur. J. Neurosci. 23(6), 1585-1595.

Zamoner, A., Funchal, C., Jacques-Silva, M.C., Gottfried, C., Barreto Silva, F.R., Pessoa-Pureur, R., 2007. Thyroid hormones reorganize the cytoskeleton of glial cells through Gfap phosphorylation and Rhoa-dependent mechanisms. Cell Mol. Neurobiol. 27(7), 845-865.

Надійшла до редколегії 24.03.2014 